\title{
The Barriers and Challenges of Corporate Governance in Jordanian Companies: An Evaluation of the Reality of Corporate Governance in Jordan
}

\author{
Houda Qasim Aleqedat \\ Faculty of Economics and Social Sciences, Szent Istvan University, Hungary
}

\section{A B S T RA C T}

Purpose: This paper aimed to identify and analyze the obstacles fronting the application of corporate governance in Jordanian companies by using collecting data from books, periodicals, previous research and interviews to access answers to questions of research.

Research Methodology: The qualitative research method and interviews have been conducted to obtain different answers to the research questions. The paper compared the data collected from articles, and the conducted interviews to inspect the extent of compliance of Jordanian legislation and companies with the corporate governance codes.

Findings: The paper concluded a unanimous agreement that corporate governance is a critical feature in business success. However, the paper provides critical findings on the barriers and the challenges of corporate governance that hinder its effective implementation in Jordan. The findings indicate a number of barriers that impeding the effective implementation of corporate governance. These barriers include non-compliance with all principles of governance, there is no general implementation of the concept in its entirety till now, this may be because the guidelines of corporate governance are indicative and non-binding as they aim to elevate the management level in companies and keep the privileges of shareholders. Therefore, it is worth recommend here to adopt this issue in future research by studying how to overcome these barriers, which may positively affect companies since good corporate governance supports poor corporate governance companies to enhance their performance and attract foreign investors.

Originality/value: The significance of this study stems from contribution to the literature by filling out the gap between theory and practice of corporate governance. This paper will contribute to

\section{ARTICLE INFO}

Article History:

Received : 25-01-2020

Revised : 21-06-2020

Accepted : 28-06-2020

Published : 30-06-2020

Keywords:

Corporate Governance (CG)

Public Shareholding Companies

Barriers

Challenges 
the knowledge by increasing the awareness of the positive effects of full implementation of principles of CG on the environment of work on the ground. In particular, applying the basics of the guidelines of corporate governance. Whereas, if the guidelines of corporate governance are applied in accordance with international best practices in this regard (theoretical implications and managerial implications), It will provide the best rules, structures, and processes that enhance confidence in the institution, as well as provide justice, responsibility, duties, and lucidity and provide confidence and tranquility to its customers. In other words, the implementation of corporate governance in business organizations is the base for increasing performance and achieving goals. In addition, it stimulates the companies to adherence to the guidelines of professional conduct. As well as finding mechanisms to promote ethical behavior which in turn reflect the commitment with applicable laws that influencing attitudes of employees. In addition, the current study may serve the researchers as an input for future research.
${ }^{*}$ Corresponding Author E-mail:

hudaeqedat@yahoo.com

Copyright $\Subset 2020$ Authors. This is an open access article distributed under the Creative Commons Attribution License, which permits unrestricted use, distribution, and reproduction in any medium, provided the original work is properly cited.

\section{INTRODUCTION}

Corporate governance is becoming a vital issue of the modern era that purposes to separate management from ownership. Conflict of interest is considered one of the main factors that headed to the failures in the economy, CG was used to eliminate the conflict of the interests between the management and other stakeholders (owners, creditors, investors, and workers) in the similar project. It is noticeable that the collapse that occurred in many countries. Despite practicing governance it may indicate that there are obstacles or challenges in applying this governance properly.

Jordan is distinguished as one of the countries of the Middle East, which has been characterized by political troubles since an era ago. Also, Jordan's economic sector faced many challenges because of the financial crises that ultimately affected the country's economy. Hence CG might be effective to meet these challenges by the implementation of the guidelines of CG in the institution.

This paper purposes to detect and analyze the obstacles and challenges facing the application of CG in Jordanian companies. The qualitative research method was employed by conducting interviews with professional persons (managers, boards of directors) to answers the research questions. In addition, the paper reviewed the articles that addressed the difficulties in applying the guidelines of CG in Jordan. The data has been collected from these interviews, scientific articles summarized the barriers impede implementing a good practice of CG.

The paper concludes that companies still facing weaknesses in the procedures of implementing and commitment to the guidelines of CG. This reason is due to the guidelines of CG are indicative and non-binding as they aim to elevate the management level in companies and keep the privileges of shareholders. Also, the paper concludes a unanimous agreement that CG is a critical feature in business success. However, there are still some restrictions and barriers that impede the progress of good practices of CG. Hence the justification for conducting this study to try filling the gap between theory and practice of CG to overcome these barriers, and to attain effective solutions by full implementation of principles of CG which may effects positively on 
on the environment of work. Whereas, if the guidelines of CG are applied in accordance with international best practices in this regard, it will provide the best rules, systems, and procedures that enhance confidence in the institution, also provide justice, responsibility, duties, and lucidity and provide confidence and tranquility to its customers. In other words, CG and its application in business organizations are the basis for developing performance and achieving goals.

\section{Importance of paper}

This paper is distinguished by shedding light on the problems facing Jordanian companies and the solutions proposed in previous research. As well as clarifying the reasons for continuing these problems and suggest effective solutions for these problems.

\section{Problem statement:}

Jordan is distinguished as one of the countries of the Middle East, which has been characterized by political troubles since an era ago. Also, Jordan's economic sector faced many challenges as a result of the financial crises that ultimately affected the country's economy.

Hence the question may arise: Is corporate governance might be effective to meet these challenges by implementing good CG in institutions. The paper seeks to answer the following questions:

1. What are the obstacles and challenges facing companies in Jordan?

2. Does an adherence to the guidelines of corporate governance in Jordanian companies lead to overcoming these obstacles?

\section{Research objective:}

The paper pursues to attain the following goals:

1. Identify the obstacles and challenges facing the implementation of corporate governance in Jordanian companies.

2. Verify the reliability of the orientation towards the implementation of corporate governance in Jordanian companies.
3. Suggestion effective solutions for the obstacles and challenges facing the implementation of corporate governance in Jordanian companies.

\section{LITERATURE REVIEW}

Corporate governance is broadly defined in the literature. Among the most important of these definitions is the definition (OECD, 2004) that defines CG as a construction between the stakeholders of the company. (Bawaneh, 2011) defines CG as the scheme of laws, guidelines, and aspects that regulator the processes of a company. The International Finance Corporation (IFC) defines it as the structure that managed and organized the company (Alamgir, 2007).

CG is becoming a vital issue later the financial breakdowns of global companies, for example, the failure of (Enron and the Arthur-Anderson), which led many investors to invest their money in the companies that characterized by good practices of CG. The literature demonstrated the importance of CG (Al-Juaidi, 2007) shows that the significance of CG stems from its role in improving and restoring the confidence of shareholders and investors in companies and the outcomes of its business. This would enhance the investment decision-making process as good CG is a vital input into the process of economic and investment decision-making. (Abdel Hafiz \& Abdul Razzaq, 2009) indicate the good CG companies characterized by management that preserving the benefits of society and employees and reaching the highest levels of work effectiveness.

The literature in Jordan addressed some studies that assessed CG in Jordanian companies.

1. (Khoury, 2003) indicates that CG consists of critical elements that raise its quality. Further, (Khoury, 2003) believes that CG is available in the Jordanian business environment (Legislative framework). However, the researcher indicates that there are areas for improving and strengthening the guidelines of CG in Jordan and filling the gaps in their implementation.

2. (Bashiti \& Rabadi, 2006) evaluate the CG in 
Jordan, the author indicates that Jordan has made great strides in drawing up and implementing CG policies, As it sought to advanced regulation of the financial market, the formation of a corporate observer function, and the issuance of an investment promotion law, but these are theoretical matters that have not meticulously applied on the ground.

The study was conducted on 44 companies, representing $46 \%$ of the shareholding listed companies in the financial market. The study concluded that the Jordanian financial market is becoming more sophisticated, which requires from shareholding companies preparing a high level of report, and raising the level and periodicity of its reports and communications. Furthermore, the study reveals that CG doesn't fully implement, and the researcher indicates that many companies do not have an audit committee and he recommends that this mechanism be addressed as it is a critical mechanism for CG in future studies.

3. (Al-Oqdah \& et al., 2009) examined the problems facing Jordanian economic establishments and the function of internal audit to attain the goals of CG. Also, the study inspected the application of the guidelines of CG in Jordanian companies, the study shows a weakness in the implementation of these principles, especially in Jordanian banking institutions. Furthermore, the study indicates that Jordanian companies facing a conflict of interest problem. And no separation between ownership and management has been achieved in Shareholding Listed Companies. Also, there is a weakness in the external and internal oversight institutions in identifying companies problems due to lack of independence. The lack of internal audit in many companies, as well as audit committees. The guidelines of CG are dispersed and distributed in more than one law or regulation in financial legislation (corporate law, banking law, etc.

4. (Matar \& Noor, 2007) examine the degree of the commitment of Jordanian banking and industrial companies to the CG principles. The study shows that the level of commitment of companies in the two sectors ranges between strong and very weak and that the weakness in the application is rooted mainly in the failure of the boards to follow to the rules of professional conduct as it should. Besides, not all stakeholders are involved in strategic decisions making.

5. (Yamin and Al-Ramahi, 2016) The study examined the extent of the insurance companies committed to the application of CG in Jordan, the CG was measured by using the CG guidelines (ensuring an effective framework for CG, declaration, and lucidity, the stakeholder's task, Board responsibilities, similarly treated for Shareholders, keep the privileges of shareholders), the role of stakeholders was applied as the best principles. While the principle of similarly treated for Shareholders was the least applied. The study finds the applying of the CG guidelines in Jordanian insurance companies to a medium degree. Furthermore, the study illustrated no-compliance of the boards of directors and managers to the guidelines of proficient behavior. However, published data have a shortage in the disclosure and transparency demands. The study endorses that insurance companies should be required to apply all guidelines of $\mathrm{CG}$ on the ground to eliminate the forgery of business results.

6. (al-Qashi and al-Khatib, 2006) The study targeted to analyze the reasons of the collapse of the (Enron) company, whose led to the collapse of the largest auditing company in the world (Arthur Andersen) and review the recent changes to the CG due to these collapses, And the probability of applying these changes on the ground. The study finds that the main problem with the breakdown of the company was related to the low of professional ethics. Also, there is a shorten by the financial market as an oversight body for listed companies. Further, there is difficulty in applying the modern concept of CG by auditors and the companies in the market. The problem does not lie with the laws governing CG in general, but rather with the ethics of the people 
applying those laws.

The following table summarizes the main deficits in the carrying out of the CG principles in Jordanian companies:

\section{CORPORATE GOVERNANCE IN JORDAN Background}

Most of the shareholding companies tend to separate ownership and management currently as the main mechanism of corporate governance. Therefore, owners trying to choose suitable boards that employ they hire competent managers. This issue has become one important mechanism of governance in Jordan. In response to the financial crises, the government in Jordan issued laws related to CG to support the economic situation. The Securities Depository Centre (SDC) issued the Codes of CG which drawing from (OECD) the Organization for Economic Cooperation and Development Principles of CG and the different lows and its regulations and instructions, namely, Banking Law; companies Law; Securities Law; Law of the profession of legal accounting. These codes namely, Shareholding Companies listed on the Amman Stock Exchange, CG Code for Banks, CG Instructions for Insurance Company, Jordanian CG Code (Private Shareholding Companies, Limited Liability Companies, and Non-Listed Public Shareholding Companies). The key goal of these codes is to regulate the relationship and illustrate the rights, obligations. Despite the troubles of the Middle East, the economy in Jordan trying to overcome these troubles, so the government issued the legislations of CG that mentioned above to rebuild confidence to investors.

\section{Problem of corporate governance in Jordan}

Jordan has taken an advanced step by issuing codes of $\mathrm{CG}$, as these guidelines were launched on $1 / 1 / 2007$. It was decided to apply these rules initially through the "commitment or interpretation of non-compliance" approach, to give companies flexibility in implementation and sufficient time to adapt to the requirements of the rules of governance. Consequently, awareness of these rules is strengthened. Despite this, companies are still at the moment required to apply these rules, optionally. Therefore, since Jordan characterized by a lack of governance system as a developing country. Also, it has trouble in foreign direct investment (FDI) (Rafiee and Sarabdeen, 2012). Furthermore, since CG measured the success of economic and reflects the translucency and responsibility. So, Jordan must enhance the tools of CG by obliging the shareholding companies to implement these principles compulsorily.

Regarding the laws and legislations in Jordan,

Table 1. Most important shortcomings in the implementation of the principles of corporate governance in Jordanian companies

\begin{tabular}{|c|c|}
\hline Deficits & Authors \\
\hline Corporate governance is not fully implemented in Jordan & $\begin{array}{l}\text { (Khoury, 2003; Bashiti \& Rabadi, 2006; Al-Oqdah \& et al., } \\
\text { 2009; Matar \& Noor, 2007; Yamin and Al-Ramahi, 2016; } \\
\text { al-Qashi and al-Khatib, 2006) }\end{array}$ \\
\hline Lack of audit committee & (Al-Oqdah \& et al., 2009; Bashiti \& Rabadi, 2006) \\
\hline $\begin{array}{l}\text { Non-compliance of the boards of directors to the rules of } \\
\text { professional conduct. }\end{array}$ & $\begin{array}{l}\text { (Yamin and Al-Ramahi, 2016; Matar \& Noor, 2007; al-Qashi } \\
\text { and al-Khatib, 2006) }\end{array}$ \\
\hline $\begin{array}{l}\text { - The Jordanian companies suffering from a conflict } \\
\text { of interest problem. }\end{array}$ & (Al-Oqdah \& et al., 2009) \\
\hline \multicolumn{2}{|l|}{ - No separation between ownership and management. } \\
\hline \multicolumn{2}{|l|}{ - Lack of independence of the oversight institutions. } \\
\hline \multicolumn{2}{|l|}{$\begin{array}{l}\text { - Dispersion and distribution of the Principles of corporate } \\
\text { governance in more than one law or regulations. }\end{array}$} \\
\hline $\begin{array}{l}\text { - Lack of commitment to provide the disclosure and } \\
\text { transparency requirements of the published data. }\end{array}$ & (Yamin and Al-Ramahi, 2016) \\
\hline
\end{tabular}

Source: (Author's own, 2020) 
it is noticed a conflict between these laws and the CG guidelines. For example, the Companies Law No.(22) or year 1997 allows founders to own $75 \%$ of the shares in banks and insurance companies and $50 \%$ of the shares in other shareholding companies, and they elect the board directors and the related committees which might lead to competing interests. Furthermore, Article (152 / c) of the Jordanian Companies Law did not stipulate the segregation between the role of the chairman and the general manager, while the principles of CG don't permit combining these two positions (Chairman and an executive position).

It is notable here that there is a shortage in the literature regarding the problem that arises in Jordan CG, for example (Shanikat, and Abbadi, 2011) evaluates the realism of CG in Jordan by using the five major principles of CG. The paper concluded that Shareholders are not given some of their basic rights such as their participation in large decision making. Further, they were not treated fairly in practice. He emphasized the existence of disclosure and transparency to a large extent, but in terms of quantity and not qualitative. (Aladwan and Tahtamouni, 2016) clarified most of the main regulations that regulate CG in Jordan outmoded and it is necessary for issuing a recent regulation of CG to secure good practices of CG by merging all the codes that oversee CG in integrated one concerning principles of new CG for the Organization for Economic Cooperation and Development in 2015. Here it worth to assert that the local literature in Jordan emphasized that the implementation of CG policies is a theoretical matter that has not been accurately implemented on the ground and has not been fully implemented such as (Al-Oqdah \& et al., 2009) indicate that Jordanian companies facing a conflict of interest problem. (Matar \& Noor, 2007; Yamin and AlRamahi, 2016) assert that the level of commitment of companies is not strong, and this due to the failure of the boards to follow the rules of professional conduct. At the same line (al-Qashi and al-Khatib, 2006) assert that the main problem with the breakdown of the companies was related to the low of professional ethics which means the problem lies with the ethics of the people applying those laws NOT the laws governing CG in general.

In Summary, although corporate governance in Jordan played a main function in treating the problems of companies, many companies still suffering from some problems have not addressed. Upon reviewing the literature of CG in Jordan and reviewing some laws and guidelines. It is clear that some lawful problems and obstacles hinder attempts to treat the company's problems and hinder the carrying out of CG principles. Among these obstacles are the absence of segregation between ownership and management, the absence of audit committees, the lack of separation between the chairman and the general manager. Failure to compel companies to issue reports associated to CG in an obligatory manner. Therefore, legislative organizations in Jordan must taking these obstacles and problems into consideration and work to motivate companies to implement all the principles of CG in a mandatory manner to achieving to well-organized CG assists poor CG companies to enhance their performance and attract foreign investors.

\section{RESEARCH METHOD}

\section{Research Design}

The research is designed in a way that aims to ensure access answers to questions of research and to address the research problem efficiently. Therefore, this paper adopted the theoretical and analytical method, where a scheme has been developed for data collection and analysis, the data derived from books, periodicals, and previous research. The paper compared the articles that addressed the difficulties and barriers in implementing good CG practices in Jordanian companies seeking to examine the extent of compliance of Jordanian legislation and companies with the principles of CG.

The qualitative research method adopted by conducting interviews with professional persons to obtain different answers to the research questions. The official letter has been sent to respondents include academic qualifications, as well as the objectives of the paper and the important topics to be discussed in the interviews. 
Later, a telephone call confirmed the letter and presented clarification about the topics to create the first impression of the proficiency of the researcher. (40) Companies from different sectors were selected to filling out the questionnaire and (30) interviews were conducted with proficient persons (managers, the board of directors, employees) to obtain different answers to the research questions. The researcher designed a series of questions twenty sub-questions to conclude the barriers of implementation of effective CG. These questions stem from the two main questions of the study problem which were developed from the literature and codes of principles of CG in Jordan.

To assure the validity of research and to get different sides on the subject of study. The researcher employed the Triangulation as a qualitative research strategy by using different methods to collect data and numerous categories of samples (managers, the board of directors, employees) in different sectors (Industry sector, Service sector, financial sector). The data were collected from different methods: reviewed literature (books, websites, periodicals, and previous research); questionnaire; and interviews. These collected data have been analyzed regarding the challenges that impede the implementation of CG in Jordan.

Regarding the internal and external validity of a study that reveals the reliability of the results of a study. Internal validity (structure of study), whereas the external validity reflects how the results are applied to the real world. Internal validity, this study establishes the association between the employment of $\mathrm{CG}$ and the challenges of companies that examine if the CG principles are applied in agreement with global best practices, and what is if these principles may overcome the challenges facing by companies. The higher the internal validity means the higher trust in the findings. The internal validity of the study becomes when alternative interpretations of the study results are absent. To improve the internal validity of a study, the study conducts a research design that raises the possibility of rejecting the alternative hypotheses. This was achieved through selected the sample randomly in a manner in which they are representative of the population of the study.

External Validity reflects if the findings can be a generalization.in other words, the findings can be applied to other people, situations. To improve the external validity of the study. The study defined the population in a clear way. In addition, the study conducting with different samples and it gets the same results. Furthermore, the study adopted the meta-analysis by depending on a large number of studies that reflect the same results on the same topic.

\section{Data collection}

The data was obtained from reviewed literature: (books, websites, periodicals and previous research); questionnaire; and interviews.

\section{RESULTS AND DISCUSSIONS}

Literature refers to the leadership and entrepreneurial role of management and indicates the functions and tasks exercised by the management in organizing, planning, controlling and making decisions, which makes them deserve the rights and privileges guaranteed by various laws, which formed the culture of the board directors and the environment which it runs. From here stems the role and significance of CG to govern and shape this environment to ensure manage the company without any competing interests and guarantee the privileges of stakeholders, in particular, shareholders control their companies in a limited way, whereas boards of directors turn in a decisive role in management (Aleqedat, 2018). However, (al-Qashi and alKhatib, 2006) indicates a failure by Jordanian companies to adhere to the execution of all principles of CG, and this shows that stakeholders from higher positions who oppose the ideal implementation of these principles, which contradicts their benefits and gains. For this reason, CG may not be a radical solution to the problems of Jordanian companies. (Khoury, 2003) Asserts that the frame of CG reflects the quality of it and CG and this frame is available in the 
Jordanian business environment (Legislative framework) but it requests to develop and strengthening and filling the gaps in their implementation.

The literature illustrates that there are difficulties confronted the implementing perfectly CG performs in Jordanian companies. As a ground, the excessive struggle now faced in the carrying out of CG is a moral problem (ethics of the people whose applying laws) much more than laws governing CG in general (al-Qashi and al-Khatib, 2006). The Board of Directors has more authority to make decisions during the employment of the governance process, which reduces the authority of the company's creators (Argentino and etal., 2017). This may lead to conflicts of interest between them, this confirmed by (Jensen \& Meckling, 1976) the owner appoints the manager to manage the company agreeing to their interests, but in practice, the interests of the manager do not always meet the interests of the owner, where the conflicts of interest are happening. The paper compared the articles related to the assessment of CG in Jordan, all of them agreed there are various obstacles and difficulties in the carrying out of implementing good governance performs and the findings gained were very nearby.

This paper discussed various aspects of difficulties in the execution of the good performs of CG. This section will include the most important points on which the articles focused on obstacles in applying CG. As well as the most important answers obtained from the responses through interviews. (Bashiti \& Rabadi, 2006) indicates that Jordan has made great strides in drawing up CG policies, but these policies have not been exactly applied on the ground. Where most studies (Bashiti \& Rabadi, 2006; Al-Oqdah \& etal., 2009; Yamin and Al-Ramahi, 2016) confirm that codes of CG don't fully implement in Jordanian companies, in particular, the existence of audit committee, lack of internal audit, and separation between ownership and management. Further, (Yamin and Al-Ramahi, 2016) reveal that the insurance companies do not apply the rules of professional conduct effectively, as well as not providing the requirements for disclosure and transparency in the published data, and do not treat shareholders equally.

It might be expected the origin of existence deficiency in the implementation is rooted mainly in the failure of the boards of directors to adhere to the rules of professional conduct. This could be because of the Jordanian financial market is becoming more sophisticated (Matar \& Noor, 2007). As a result, Jordanian companies still suffering from a conflict of interest problem. And this will be becoming worse due to a weakness in the external and internal oversight institutions in the legislations environment.

Regarding the answers obtained from the responses through interviews. Most interviewees agreed that CG is a critical issue and measurement of business accomplishment. Also, it is a main tool of strength to ensure there are transparency and responsibility in the work environment. On the other hand, respondents were unanimously agreed that the principles of governance are not fully and effectively implemented in Jordanian companies. Most respondents reported that conflicts of interest still exist and the lack of desire of some people to apply CG effectively, because that opposes their interests, and therefore there must be a move from the higher authorities of the state to put a hand on the main reason for the existence of obstacles in the application of these principles. Some respondents indicated that the failure of some companies in the implementation due to the absence of fines and penalties.

The respondents suggested focusing on the reasons for the lack of implementation of principles. Also, forcing the companies to cover this deficiency by issuing strict and binding instructions to implement these principles. The following table 2 summarizes the most important responses of the respondents.

Based on the collected data from the reviewed literature and interviews regarding the challenges that impede the execution of CG in Jordan, the 
paper summarized:

1. There is still a failure to obey the full execution of codes of CG in Jordanian companies. Such as no separation between ownership and management in some of shareholding listed companies. As well as most companies do not have an audit committee and internal audit.

2. Failure to implement these codes may indicate that there are stakeholders from higher positions who oppose the ideal implementation of these codes, which in turn opposes their interests and gains. For this reason, CG may not be a radical solution to the problems of Jordanian companies.

3. There is a conflict between laws and the codes of CG in Jordan which might cause competing interests and impedes applying the CG codes efficiently.

4. Comparing the texts of the companies' law with the codes of CG, it became clear that the companies law needs to be amended in order to facilitate and accelerate the process of implementation of CG procedures, their followup, and the monitoring and evaluation of their implementation.

5. The structure of CG is available in the Jordanian business environment (Legislative framework) but it needs for improving and strengthening and filling the gaps in their implementation.

6. There is a weakness in the external and internal oversight institutions in identifying companies' problems due to the lack of independence of these institutions.

7. The principles of CG are dispersed and distributed in more than one law or regulation in financial legislation (corporate law, banking law, etc....)

8. The problem lies in the ethics of the people who apply the laws of CG, not laws governing CG in general.

9. Most of the companies 'boards of directors are consist of members who are not professionally specialized, especially in the field of financial accounting.

10. Lack of effective monitoring and follow-up by the Amman stock exchange to ensure the effective implementation of CG in the public shareholding listed companies.

In summary, despite the troubles of the Middle East, the economy in Jordan trying to overcome these troubles, where the government issued the legislations of CG to rebuild confidence to investors. The Jordanian government has tried to motivate Jordanian companies to implement CG, since 2007. However, companies are still applying these rules, optionally till the moment as there is no mandatory implementation and there is still a weakness in the procedure of implementing and commitment to the CG codes. There is no general implementation of the concept in its entirety, and the reason is that the rules of CG are indicative and non-binding as they aim to raise the level of management in companies and protect the rights of shareholders.

New procedures have been taken recently from Amman Stock Exchange by issued new instructions related to the governance of public shareholding

Table 2. Most important responses

\begin{tabular}{|c|c|c|c|c|}
\hline No & Sector & Type & Position & Opinion \\
\hline 1 & Industry sector & Manager & $\begin{array}{l}\text { Chief Operating } \\
\text { Officer (COO) }\end{array}$ & $\begin{array}{l}\text { The absence of full implementation in CG principles led } \\
\text { to a failure in some economic institutions. }\end{array}$ \\
\hline 2 & Industry sector & Employee & Employee & $\begin{array}{l}\text { The company which apply the tools of governance } \\
\text { effectively it can cope with the administration crisis. }\end{array}$ \\
\hline 3 & Service sector & Manager & General manger & $\begin{array}{l}\text { The CG principals raise the level of management in } \\
\text { companies and protect the rights of shareholders. }\end{array}$ \\
\hline 4 & Financial sector & Head of section & $\begin{array}{l}\text { Head of internal } \\
\text { Audit department }\end{array}$ & $\begin{array}{l}\text { The lack of independence of internal control in most } \\
\text { companies affects the quality of reports. }\end{array}$ \\
\hline 5 & Industry sector & Manager & CEO & $\begin{array}{l}\text { Most of the Boards of directors consist of } \\
\text { non-professional members. }\end{array}$ \\
\hline
\end{tabular}

Source: (Author's own, 2020) 
companies for the year 2017 as a motivational step to encourage Jordanian companies to adhere to these codes of CG. The main instructions are to emphasize the necessity to adhere to the formation of the Board of Directors and clarify the tasks and duties of the Board of Directors and the formation of committees emanating from this Council such as the Audit Committee, the Governance Committee, the Nomination and Remuneration Committee, the Risk Management Committee, the meetings of the board of directors, and the most important issue is the necessity of commitment to prepare a CG report.

It is worth noting here that some researchers showed that the legislative environment in Jordan is ready to be a basis for developing good CG procedures, but based on the weaknesses mentioned earlier, there are still shortcomings in implementing the process. Therefore the government must compel companies to apply comprehensive CG to achieve maximum benefit from it and raise the efficiency of the market. Whereas, CG measured the success of economic and reflects the translucency and responsibility. Further, applying codes of CG in all its aspects on the ground may reduce the manipulation of business results and rebuild trust in these companies. And since Jordan characterized by a lack of governance system as developing countries and it has trouble in foreign direct investment (FDI). Jordan must oblige the shareholding companies to implement the codes of CG compulsorily.

Finally, despite a unanimous agreement that CG is a critical factor in corporate success, there are some restrictions and barriers that hinder the progress of good practices of CG. Therefore, it is necessary to recommend here to adopt this issue in future research by studying how to overcome these barriers, which may positively affect companies.

\section{CONCLUSION}

Depending on the objectives of paper that identifying the obstacles and challenges facing the execution of CG in Jordanian companies. The researcher reviewed the literature and compared the articles that addressed the difficulties in executing the guidelines of CG in Jordan. It was clear that there are no local articles in this regard. Further, the researcher examined the collected data from the interviews, scientific articles to clarify the obstacles and challenges that hinder the good application of CG.

The paper concluded it is agreed that CG is a critical issue and measurement of business accomplishment. Also, it is a main tool of strength to ensure there are transparency and responsibility in the work environment. As well as there is agreed that the principles of governance are not fully and effectively implemented in Jordanian companies on the ground despite the efforts of government by issuing the legislations and the codes of CG to motivate the companies to implement CG, since 2007. Since the rules of CG are indicative and non-binding.

Also, the paper concluded that there are various obstacles and difficulties in the carrying out of implementing good governance performs. the origin of existence this deficiency in the implementation is rooted mainly in the failure of the boards of directors to adhere to the rules of professional conduct this due to that Jordanian financial market is becoming more sophisticated and this could be caused the conflict of interests in Jordanian companies which becoming worse due to a weakness in the external and internal oversight institutions.

Finally, it has been indicated by some authors that the legislative environment in Jordan has a basis for developing good CG procedures but the existence of challenges hinder implementing the good practices of CG. Therefore, the government should compel companies to fully implement the principles of CG and overcome the problems arise from this CG as well as overcome the barriers that hinder the effective application to achieve maximum benefit from it and raise the efficiency of the market as CG measured the success of economic and reflects the translucency and responsibility and reduce the manipulation of 
business results and rebuild trust in these companies.

\section{THE IMPORTANCE OF RESEARCH FOR THE FUTURE}

This paper contributes to the knowledge by increasing the consciousness of the conception of CG and classify the obstacles and challenges fronting the execution of CG in Jordanian companies. Furthermore, this paper clarifying the positive effects of the full implementation of codes of CG on the environment of work. The paper suggested effective solutions and stimulate the companies to a commitment to the rules of professional conduct. As well as finding mechanisms to promote ethical behavior which in turn reflect the commitment with applicable laws that influencing attitudes of employees. Also, convey the opinions of employees about the governance in different companies in Jordan.

The paper tried to fill the gap between theoretical and carrying out of CG (what should be applied according to the principles of governance and what is being applied on the ground). The paper recommends the implementation of governance codes on the ground. In particular, applying the basics of CG codes such as separation between ownership and management, forming audit committees, compel companies to issue reports associated with CG in an obligatory manner. Furthermore, this paper recommends intensive efforts that must be directed in the future to conduct research on the problems that arise from CG in the Jordanian context that contribute to highlighting these problems more broadly and clearly. As well as, conducting studies that show and confirm the positive effects of the full implementation of CG policies.

\section{RECOMMENDATIONS AND THEORETICAL IMPLICATIONS AND MANAGERIAL IMPLICATIONS}

The paper provides practical implications (recommendations) to fill out the gap between the theoretical and carrying out of CG in Jordan to provide a good and healthy environment and full commitment to the CG codes that is the best solution to overcome the obstacles, which will raise the efficacy of companies that will return on the economy.

In the following, the most important practical implications (recommendations) were concluded from the paper:

\section{Recommendations}

1. Urging all public listed companies to commit to fully implementing CG principles such as separation between the chairman and general manager, create internal audit departments, audit committees, risk management unit, promotions committee, governance committee, and a compliance committee. As an important mechanism to attract investors to reduce the manipulation of business results and restore confidence in the published financial reports.

2. Spreading the conception of CG further and clarifying its positive impacts to attain a better practice of the principles.

3. The possibility of re-drafting some Jordanian financial legislations, especially the Companies Law, to attain the interests of companies and CG accordingly, to eliminate the role of management, because management and ownership in Jordan have not been completely separated. Furthermore, in order to facilitate and accelerate the process of implementation of CG procedures, their follow-up, and the monitoring and evaluation of their implementation.

4. The necessity of the existence of regulatory institutions to monitor and follow-up to ensure CG is actually applied in the companies and to conduct a periodic evaluation for CG. In addition, linking CG institutions to anticorruption agencies to guarantee the controlling of governance processes.

5. Issue a periodical report on the achievements and obstacles of CG in Jordanian companies.

6. Eliminate the conflict between CG and laws and legislations such as a separation of ownership from management, and homogenization of the functions of the board to achieve a successful application of CG.

7. Raising the level of reports of public 
listed companies, and commitment to prepare the governance report.

8. The necessity of setting and developing methods (ethics) of CG and stimulating companies to prepare reports for these ethics. As well as motivating shareholders to participate in developing such ethics. Furthermore, directing the efforts to this issue in future studies.

9. Stimulate the companies to a commitment to the rules of professional conduct. As well as finding mechanisms to promote ethical behavior which in turn reflect the commitment with applicable laws.

10.Inclusion specific penalties for each legal violation of any code of CG in the laws and the legislations.

\section{Theoretical Implications and Managerial Implications}

The term governance means in its general sense good governance and represents the practices by which companies are managed and the ability to control well to run their business. It also leads to a process of balance between the goals of the institution, whether economic or social, with the interests of individuals, then the efficient use of available resources by providing oversight Sound accounting provides all the data required for accountability on how to manage the resources of this organization. Despite the novelty of this term, the need to apply it in business organizations has become a reality to protect private funds and ensure the safety of these organizations, especially after the widespread financial and administrative corruption phenomenon in many major companies around the world.

Whereas, if the principles of CG are applied following the international best practices in this regard, it will provide the best rules, systems, and procedures that enhance confidence in the institution, as well as provide justice, responsibility, accountability, and transparency and provide confidence and tranquility to its customers.

In the light of above, it is necessary for issuing a modern regulation of $C G$ to ensure good practices of CG by merging all the codes that oversee CG in integrated one with regards to principles of newest CG for the Organization for Economic Cooperation and Development. Which leads to positive effects of the full implementation of CG policies that mentioned above and contribute to eliminate the conflict of interest, as well as emphasize on and stimulate the boards to follow the rules of professional conduct.

Finally, we can summarize that the effective implementation of corporate governance in business organizations is the base for evolving performance and achieving goals.

\section{REFERENCES}

Abdel Hafiz, Shafak;, Wissam. (2009). The Role of Corporate Governance in Administrative Reform, University of Baghdad. www.nazaha.iq/search_web/muhasbe/6.doc

Aladwan, Ashraf; Tahtamouni, Moayyad.(2016).Corporate Governance Legislations in Jordan Comparative Study, European Journal of Social Sciences, Vol. 52 No 3, pp.342-357

Alamgir, M. (2007). Corporate Governance: A Risk Perspective, paper presented to: Corporate Governance and Reform: Paving the Way to Financial Stability and Development, A Conference organized by the Egyptian Banking Institute, $7-8$.

Aleqedat, Houda; Juratli, Ahmad. (2018). 21st Century Challenges in Corporate Governance and Management, the international journal of business \& management, Vol 6 Issue 11, ISSN 2321-8916, p 113-119. 
Al-Qashi, Zahir; al-Khatib, Hazem.(2006). Corporate governance between the concept and the possibility of its application on the ground in companies listed in the financial markets, Irbid Journal of Scientific Research, Volume 1, First Issue.

Al-Oqdah, Saleh; Jouda, Abdel-Hakim \& Saadeh, Youssef. (2009). The Future of Corporate Governance in Jordan, Researches of the University of Applied Sciences conference, Amman, Jordan.

Al-Juaidi, Omar. (2007). Level of Corporate Governance and its Impact on Corporate Performance: An Empirical Study on Companies Listed on the Amman Stock Exchange, Unpublished Doctoral Dissertation, Arab Academy for Banking and Financial Sciences, Amman, Jordan.

Argentino, L.G., Sousa, J.L., Nose, E.T., Petraglia, I.C., \& Rosini, A. (2017). Barriers and difficulties that may be found in the process of implementing corporate governance in companies : a study of the management process and the disclosure of information. RISUS - Journal on Innovation and Sustainability, volume 8, número 1., ISSN: 2179-3565

Bashiti, Lubna; Rabadi, Aram. (2006). Assessing Corporate Governance in Jordan, The Arab Bank Review, Vol.8, No.1.

Jordanian Companies Law No. (22) of 1997 and its amendments.

Jensen, M., \& Meckling, W. (1976). Theory of the firm: Managerial behavior, agency costs, and ownership structure. Journal of Financial Economics, 3(4), 305-360.

Khoury, Naim Saba. (2003), Where does Jordan stand from corporate governance, the Association of Jordanian Certified Public Accountants, the fifth professional scientific conference, under the slogan of corporate governance and continuity of enterprise, Amman, Jordan

Matar, Mohamed and Nour, Abdel Nasser (2007). The extent of commitment of Jordanian public shareholding companies to the principles of corporate governance: A comparative analytical study between the banking and industrial sectors, the Jordanian Journal of Business Administration, Volume 3, No. 1, pp. 46-70.

OECD. (2004). OECD principles of corporate governance. OECD PUBLICATIONS, 2, rue André-Pascal, 75775 PARIS CEDEX 16, PRINTED IN FRANCE, (26 2004021 P) ISBN 92-64-01597-3 - No. 535332004

Rafiee, V. \& Sarabdeen, J. 2012, 'The cultural influence in the practice of corporate governance in emerging markets', Communication of IBIMA, vol. 2012, no. 2012, pp.1-10.

Securities Law No. (76) of 2002 and its amendments.

Securities Depository Center, Corporate Governance Code for Shareholding Companies Listed on the Amman StockExchange, https://www.sdc.com.jo/arabic/images/stories/pdf/corporate_gov.pdf

Shamsi S. Bawaneh. (2011).The Effects of Corporate Governance Requirements on Jordan Banking Sector, International Journal of Business and Social Science, Vol.2 No.9.

Shanikat, Mohammed and Abbadi, Sinan S. (2011). Assessment of Corporate Governance in Jordan: An Empirical Study, Australasian Accounting, Business and Finance Journal, 5(3), 2011, 93-106.

Yamin, Ismail Younes; Al-Ramahi, Nidal Mahmoud. (2016).The extent of applying the principles of governance in the Jordanian insurance companies listed on the Amman Stock Exchange, Journal of Economic Sciences, Volume 17 (2), ISSN (Print): 1858-6740, e-ISSN (Online):1858-6759 